\title{
Malaysia: 30 Years of Islamic Banking Experience (1983-2012)
}

\author{
Khiyar Abdalla Khiyar, Gulf University for Science and Technology (GUST), Kuwait
}

\begin{abstract}
Malaysia proved to be at the forefront of Islamic banking and finance by adopting a dual banking system where the conventional and Islamic banking systems co-exist. The Islamic banking has been in operation since 1983 and offers a variety of Islamic financial instruments. In such a multiethnic and multi-religious country, customers get the financial products and services they like.

In the early 1980's, the government encouraged all Malaysians to be involved in the fast-track development process with a vision to make Malaysia a fully industrialized country by the year 2020. Actually, the development of Malaysia's dual banking system is tied up with its social and economic policy and that is why it was fully supported by the country's top leadership in addition to the Central Bank, the Parliament, and the public in general.

Islamic banks can motivate Muslims to increase savings and reduce hoarding. This kind of motivation was expected to enhance their participation in the development process contributing to savings mobilization and capital accumulation in order to improve their standard of living and bring them up to par with their countrymen of Chinese origin. Among the countries with a free market economic system, Malaysia has emerged as the first country to implement a dual banking and financial system. The Malaysian model has been recognized by many Islamic countries as the model to emulate.
\end{abstract}

Keywords: Islamic Banking; Islamic Finance; Malaysia; Dual Banking

\section{INTRODUCTION}

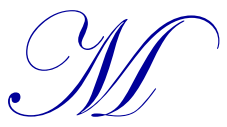

alaysia has one of the most dynamic and vibrant economies in the Southeast Asia region that is actively contributing toward economic development of Southeast Asia. In fact, Malaysia is no more regarded as a developing country as it is now included in the category of Newly Industrialised countries. Further, Southeast Asia is not a monolith. Instead, it has an amazing maze of ethnic diversity. This complexity of ethnic structure is reflected in the Malaysian society also, whose total population is estimated to be 28.6 (at the end of 2011) million people composed of 54\% Malay Muslims, 35\% Chinese, and 10\% Tamil Indians (Ahmed, 1997).

In the early 1970s, the government of Malaysia embarked on a radical policy aimed at redistributing the country's wealth. The Chinese, who make up about $35 \%$ of the population, had controlled the bulk of economic activity. In the aftermath of serious race riots and in a bid to eradicate poverty, the government brought in a series of policies. Even though the policies of the government helped in significantly reducing poverty, it could not achieve the target of raising the Malays' corporate share to 30\% by 1990. The Malays' share of corporate wealth increased from $2.4 \%$ in 1970 to about $20 \%$ in 1990 - short of the government's target of $30 \%$ by that date (Cook, 1995).

Since Dr Mahathir Mohammed became the Prime Minister of Malaysia in 1981, he encouraged all Malaysians to be involved in the fast-track development process with a vision to make Malaysia a fully industrialised country by 2020, and in 1981 he appointed a steering committee to study the possibility of establishing an Islamic banking system alongside the conventional one. In 1983, the Parliament passed the 'Islamic Banking Act' primarily to offer Muslims with reservations about conventional banking, the opportunity to 
participate in the growth of the country's financial system and economic development. Therefore, the development of the Malaysia's Islamic Financial System is tied up with its social and economic policy.

For Jaffer Hussein, the former governor of Bank Negara Malaysia (Central Bank), the new system was the realisation of a dream where he was able to see a full-fledged Islamic financial system in Malaysia functioning sideby-side with the conventional system. Mr. Anwar Ibrahim also said when he was Finance Minister and Deputy Prime Minster (Cook, 1995), "Muslims must be able to compete in the banking sector as in other areas. They must respond to changes in the financial world." He also said, "In implementing Islamic principles in banking and finance, we must address substantive issues rather than always be preoccupied with terminology and semantics."

This shows that the gradual development of the Islamic financial system was fully supported by the political leadership, Parliament, and the public. That is why it was a very successful experiment which deserves a deep study to act as a model for Muslim countries to emulate.

\section{OVERVIEW OF MALAYSIAN ISLAMIC BANKING}

Since the 1970s, Islamic banking has emerged as a new reality in the international financial scene. Its philosophy and principles are, however, not new, having been outlined in the Holy Qur'an and Sunnah of Prophet Muhammad (pbuh) more than 1,400 years ago. The emergence of Islamic banking is often related to the revival of Islam and the desire of Muslims to live in all aspects of their lives in accordance with the teachings of Islam (Bank Negara Malaysia, 1994).

The long term objective of the Central Bank (BNM) has been to create an Islamic banking system to function on a parallel basis with the conventional system. A single bank does not constitute a system. A banking system, whether Islamic or conventional, would require three vital ingredients to qualify as a system. These three ingredients are:

- a large number of players (financial institutions)

- $\quad$ a broad variety of instruments

- $\quad$ an Interbank market

In addition to these requirements, which apply to all systems, an Islamic banking system must also reflect the socio-economic values of Islam. In other words, it must be Islamic in substance and not merely a label. Recognising the above, the authorities adopted a step-by-step approach to achieve the objective of developing an Islamic banking system to complement the conventional banking.

Actually, Malaysia has emerged as an important centre of Islamic banking in Southeast Asia for its gradual development from a simple Pilgrim's Savings Corporation into a full-fledged Islamic financial system. Although the first Islamic bank in Malaysia was Bank Islam Malaysia Berhad established in 1983, Malaysia has slowly and steadily moved toward the establishment of a dynamic and vibrant Islamic financial system in the country in parallel with the conventional one.

The enactment of the Islamic Banking Act 1983 enabled the country's first Islamic Bank to be established and thereafter, with the liberalisation of the Islamic financial system, more Islamic financial institutions have been established. Malaysia's long track record of building a successful domestic Islamic financial industry of over 30 years gives the country a solid foundation - financial bedrock of stability that adds to the richness, diversity and maturity of the financial system. According to the Malaysian Banking Industry Report 1H2011, Islamic banking in Malaysia is the fastest growing sector in the global banking industry with an average annual growth rate of $20 \%$ over the past five years. To date, Malaysia has 17 Islamic banks, including Islamic units in HSBC holdings, OCBC, and Standard Chartered PLC.

Today, Malaysia's Islamic finance continues to grow rapidly, supported by a conducive environment that is renowned for continuous product innovation, a diversity of financial institutions from across the world, a broad range of innovative Islamic investment instruments, a comprehensive financial infrastructure, and adopting global regulatory and legal best practices. Malaysia has also placed a strong emphasis on human capital development 
alongside the development of the Islamic financial industry to ensure the availability of Islamic finance talent. All of these value propositions have transformed Malaysia into one of the most developed Islamic banking markets in the world.

Rapid liberalisation in the Islamic finance industry, coupled with a facilitative business environment, has also encouraged foreign financial institutions to make Malaysia their destination of choice to conduct Islamic banking. This has created a diverse and growing community of local and international financial institutions.

Malaysia continues to progress and build on the industry by inviting foreign financial institutions to establish an international Islamic banking business in Malaysia to conduct foreign currency business.

\section{BANK NEGARA MALAYSIA'S STRATEGY}

If we take a survey of the Islamic banking around the world, we find three different patterns of Islamic banking. We may categorise them as Macro model, Dual system model, and Individual bank model. The Macro model was adopted by Sudan, Pakistan and Iran. The dual model was first adopted by Malaysia, followed by Bahrain. The individual bank model was adopted by many countries. After careful consideration, the BNM allowed the existing financial institutions to offer Islamic banking services using their existing infrastructure and branches to achieve the dual banking system. This was the best strategy adopted by BNM to disseminate Islamic banking throughout the country in a short time and at minimum cost without disturbing the existing conventional financial system.

\section{DUAL BANKING SYSTEM IN THREE PHASES}

The Central Bank of Malaysia (BNM) adapted several principles and approaches in developing a dual banking system, like gradual implementation, providing adequate infrastructure, optimizing available opportunities, and openness. We divide the phase covered by Malaysia to create a new full-fledged Islamic banking and financial system into three phases:

Phase I: Foundation years cover 1963 to 1982; establishment of non-banking Islamic financial institutions like Tabung Haji.

Phase II: Developing years cover 1983 to 1993; establishment of Islamic Bank (BIMB), Govt. Investment Certificate (interest-free), Takaful companies, Labuan IOFC, etc.

Phase III: Take-off years cover 1994 to 2001; establishment of Islamic Inter-bank Market, Islamic Inter-bank Cheque Clearing System, new Islamic financial instruments, National Syariah Advisory Council on Islamic Banking and Takaful (NSAC-IBAT), and achieve a full-fledged Islamic financial system.

\section{Phase I (Foundation Years)}

Phase I covers the period 1963 to 1983 when non-banking Islamic financial institutions were established, especially the establishment and successful performance of Tabung Haji.

Royal Professor Ungku Abdul Aziz of the University of Malaya wrote a memorandum entitled "A plan to improve the economic position of future pilgrims" and submitted the paper to the Government in 1959. Accordingly in 1962, the Pilgrim's Savings Corporation was established and started its operation in 1963. Within one year of its operation, it was able to collect a total deposit of $\$ 49.600$ from 1,281 depositors. The deposits were growing steadily and within three years (i.e., by 1966), the corporation had achieved the break-even position and paid a dividend of $3 \%$. The corporation was increasingly receiving the attention of the people and government. The Pilgrimage Fund, or Tabung Haji, was established in 1969 through an Act of the Parliament - Lembaga Urusan Dang Tabung Haji Act of 1969. By 1972, the viability of interest-free financial institutions was established in Malaysia by Tabung Haji and the erstwhile Pilgrim's Savings Corporation. 
Encouraged by the successful performance of the Pilgrim's Fund Board (Tabung Haji), the Prime Minister of Malaysia appointed the National Steering Committee on Islamic Banks on July 30, 1981, in order to facilitate the establishment of Islamic banks and Islamic financial institutions.

Accordingly, the committee prepared a report and submitted it on July 5, 1982. The Government accepted the recommendations of the committee. The important recommendations, inter alia, were:

1. An Islamic Bank, which operates according to the rules of Shari'ah, should be established.

2. In order to provide for licensing and supervision of the bank, an act styled as the 'Islamic Banking Act' should be legislated and some consequential amendments should be made to the existing related Acts.

3. The bank should set up a religious supervision council to supervise the compliance of its operations with Shari'ah principles.

In 1982, the Islamic Banking Act was passed, got Royal assent in March 1983, and was published in the official gazette. The Bank Islam Malaysia Berhad (BIMB), which applied for incorporation on February 4, was incorporated on March 1, 1983, and began operation on July 1, 1983. Thus, the concept of Islamic Banking initiated in Malaysia by Prof. Ungku Abdul Aziz in the 50's, got full expression in the Bank Islam Malaysia Berhad (BIMB) in 1983 after a period of 25 years and through a continuous process of successive improvements (Ahmed, 1988).

\section{Phase II (Developing Years)}

The second phase covers the period 1983 to 1993 when many components of Islamic banking were established, like BIMB, Islamic insurance companies, and interest-free government bonds, Labuan IOFC, etc.

Islamic banking became a reality in Malaysia in March 1983 with the inception of the Bank Islam Malaysia Berhad (BIMB). Its establishment was motivated by the successful experience of similar financial institutions, such as the Pilgrim's Management and Fund Board (PMFB) in Malaysia and other Islamic banks in other countries (Bankers Journal of Malaysia, 1989).

Following the establishment of BIMB, a number of measures had been taken to strengthen other Islamicoriented institutions in Malaysia. Such measures include the revamping of Malaysia Islamic Development Foundation in 1984 and the setting up of the Islamic insurance company, known as Syarikat Takaful Malaysia Sendirian Bhd, in 1988. These developments became possible after BIMB had proved to be a viable institution due partly to the support given by the public in dealing with the Islamic banking practices in Malaysia.

\section{Establishment of BIMB (Monopolistic Years)}

Bank Islam Malaysia Berhad was established with a total paid-up capital of $\$ 80$ million. The Malaysian government provided $\$ 30$ million of the capital while the rest was provided by PMFB, the Muslim Welfare Organisation of Malaysia, state religious councils and agencies, and other Federal agencies. The Corporate objective of the bank is to provide banking facilities and services to Malaysians, in general, and Malaysian Muslims, in particular, in accordance with Islamic commercial law. In addition to its Board of Directors and Committees of Management, the bank also has a Religious Supervisory Council which consists of eminent religious scholars in this country. Setting up of the Religious Supervisory Council is mandatory under the Islamic Banking Act of 1983. The act further specifies that it is the duty of the Religious Supervisory Council to advise the bank on the operations of its banking business to ensure that its operations do not involve any element that is not permissible in Islam.

Some of these BIMB's deposits came from Muslims who had previously rejected interest-based transactions and kept their money outside the financial system. The bank has played its intended role of mobilising greater resources and deepening the financial system for the promotion of economic development in the country.

Moreover, within two years after its establishment, BIMB managed to set up three subsidiaries to cater its expanding activity: 
- $\quad$ Syarikat Al-Ijarah Sdn. Bhd. was set up in 1983 with a paid-up capital of $\$ 1$ million. This company provides capital for acquiring movable and immovable fixed assets from BIMB.

- Al-Wakalah Nominees Sdn. Bhd. was established in 1984 to act as a nominee for BIMB, its related companies, and other clients on the sale and purchase of shares, as well as the sale of collaterals.

- $\quad$ An Islamic Insurance Scheme, which was launched in 1985 under Syarikat Takaful Malaysia Sdn. Bhd., is controlled by BIMB. This scheme is in conformity with the Shari'ah law based on the principles of $\mathrm{Al}$ Takaful and Al-Mudarabah. Al-Takaful refers to a situation whereby a group in community mutually guarantees one another, while Al-Mudarabah is a business contract involving profit-sharing agreements between the Sahibul Mal (investor) and the Mudarib (entrepreneur) who conduct the actual business. The establishment of BIMB has been a catalyst to the development of other Islamic institutions in the country. One important example is the revitalisation of Bayt al-Mal in various states in Malaysia.

The Bayt al-Mal has broadened its traditional role as a Zakat disbursement body. A few Bayt al-Mals, such as in Kuala Lumpur, have successfully ventured into business and property. The gains from trading are ultimately used to help reduce economic and social inequalities among Muslims through various welfare and social programmes of the Bayt al-Mal. The re-establishment of Malaysia Islamic Economic Development Foundation is yet another effort to strengthen the Islamic financial apparatus in the country, inspired by the successful operation of Bank Islam Malaysia Berhad. Its functions are to promote education among Muslims, provide scholarships to the needy students, and acetones to those affected by disaster and calamity, and contribute to the needy institutions and organisations as approved by the Department of Inland Revenue (Bankers Journal of Malaysia, 1989).

The BIMB has an authorised capital of 500 million, divided into 500 million ordinary shares of one Malaysian dollar each. In 1983, the bank had started with a paid-up capital of M $\$ 80$ millions. At that time, it enjoyed a monopoly position in the domestic market of Islamic banking. After a period of 10 years (in 1993), the capital resources of the BIMB stood at US \$53 million. The BIMB may be viewed as a semi-public sector financial institution as the government of Malaysia has contributed 37.5 percent of its paid-up capital. Other major shareholders are: Pilgrim's Management \& Fund Board (Tabung Haji), Muslim Welfare Organisation of Malaysia, State Religious Councils, State Religious Agencies, and other Federal agencies (Zakaria, 1988).

On the basis of Shari'ah principles, the BIMB offers all the conventional banking services, such as accepting deposits, granting credit facilities, provision of safe-keeping facilities, and funds transfer. The bank accepts savings and demand deposits from members of the public under the principle of Wadiah. It also accepts term deposits in the form of general investment deposits and special investment deposits under the principles of Mudarabah. It was also listed on the main board of the Kuala Lumpur Stock Exchange on January 17, 1992.

On the prudential front, the BIMB had to adhere to the same regulatory rules as other banks offering conventional banking products. The bank is required to observe a minimum risk weighted capital ratio of $8 \%$ in effect on January 1, 1992.

\section{Government Investment Certificates (Non-Riba)}

In conjunction with setting up of BIMB, another element of Islamic banking was introduced in 1983 in the form of Investment Certificates. These certificates, which are non-interest bearing, were issued under the Investment Act of 1982 to enable BIMB to meet its liquidity requirements in terms of its holdings of liquid assets, as well as to provide an investment avenue for BIMB to temporarily park its excess funds. The holdings of certificates are, however, not restricted to Bank Islam Malaysia Berhad only, but are also available to others in the financial system. Similar to Malaysian Government Securities and Treasury bills, the certificate represents a loan to the government, except that it does not have a predetermined rate of interest. The rate of dividend is to be determined by the Minister of Finance at the maturity of the certificate. The issue of Investment Certificates is governed by the Islamic principle of Qard Hasan, which considers the purchase of these certificates as a benevolent loan to the government. The holders of the certificates therefore cannot expect any returns on their capital besides the principal amount which will be fully refunded upon maturity. The payment of dividends, if any, is entirely at the discretion of the government [Malaysia was the first country in the world to issue government bonds on an Islamic basis]. 
The Government Investment Act empowers the government to issue Government Investment Certificates (GIC). These certificates are regarded as liquid assets and Islamic banks could invest in these certificates to fulfil the central bank's requirements regarding liquidity as well as to place their excess idle fund.

In the beginning, GICs were only being issued on an experimental basis and their main function was to help the Bank Islam Malaysia - the only Islamic bank in the country at that time - in meeting its prescribed liquidity requirements as the Bank, being an Islamic bank, could not keep its liquid assets in the form of interest-bearing assets. However, since then, the GICs have acquired the character of a full scale Islamic financial instrument. Hence, these institutions wanted more GICs for meeting statutory liquidity requirement as well as to place their excess liquid funds (Ahmed, 1997).

\section{Labuan International Offshore Financial Centre (IOFC)}

The Labuan International Offshore Financial Centre (Hussein, 1998) was launched on 1 October, 1990. Its objectives were to:

- $\quad$ Complement Kuala Lumpur as a regional financial centre

- $\quad$ Strengthen the contribution of the financial services sector to the Gross National Product of Malaysia

- $\quad$ Promote the economic development of Labuan and its vicinity

A key feature of the Labuan IOFC is the wide scope of offshore financial services and products offered to customers world-wide (particularly those in Asia) covering, among others, offshore banking, offshore insurance, trust business, fund management, investment holding, Islamic financing, company management services, and capital market activities.

The scope and level of offshore financial services and activities in Labuan have increased steadily over the years and are set to gain momentum for further growth in the future. In line with the progress recorded in the area of conventional offshore financing, Labuan IOFC is now broadening its base by focusing its efforts on becoming an International Centre for Islamic financing.

The new focus is timely as Islamic banking and financing has assumed an increasingly important role in the global scene, particularly in the Islamic world. The increase in income of Muslim countries, together with the large Muslim world population coinciding with resurgence of Islamic awareness, has given rise to a strong demand for Islamic financial instruments and products. Labuan intends to meet the demands of international investors in an offshore environment that is tax efficient and well governed by a conducive legal framework.

Indeed, Labuan is strategically positioned to meet the immediate demand of Muslim investors in the region covering Indonesia, Brunei, Southern Philippines, Southern Thailand and Malaysia. It can also receive capital from Muslim investors in the Middle East looking for investment opportunities in Islamic financial products.

Labuan can help to contribute toward greater internationalisation of Islamic banking and financing. In line with the process of globalisation of financial services, Labuan is well qualified to offer to the world competitive Islamic offshore financial products, such as Islamic financing, Takaful, Islamic trusts, Islamic investment funds, and Islamic capital market instruments.

Specialised management companies have been set up to provide consultancy and advisory services to offshore players that wish to deal in Islamic products to customers with the assistance of management companies, specialising in Islamic consultancy and advisory services.

Turning Labuan into a centre with a strong niche in offshore Islamic financing is a logical extension of the advanced development of Islamic banking, Takaful, and Islamic capital market instruments in the domestic market in Malaysia. 
Islamic financiers have to gear up to meet the increasing demand for cross border Islamic finance and project financing which are rapidly expanding as a result of the globalisation of international financial markets and the development of large scale infrastructural projects in emerging economies. These are the potential areas for the offshore banks, non-bank institutions and new players in Labuan to exploit to the fullest in marketing Islamic financial instruments in line with sophisticated requirements of today's customers.

The setting up of full-fledged Islamic institutions in Labuan; namely, Islamic banks, Islamic insurance companies and Islamic advisory houses will provide the necessary focus, expertise and commitment toward development of the Islamic financial market in Labuan.

\section{Phase III (Take-off Years)}

This phase covers the period 1994 to 2001 and beyond. In this phase, main components for a full-fledged Islamic financial system were established.

In 1993, Malaysia took a further pioneering step when it introduced its dual banking system, with conventional banks being allowed to offer service based on Islamic principles. Today, more than 50 financial institutions comprising of commercial banks, merchant banks, finance companies and co-operative banks in Malaysia offer Islamic banking services. Some are domestic banks, the majority of which are owned by nonMuslims. Others, like Standard Chartered, are foreign institutions.

As we have already stated, until 1993, the Bank Islam Malaysia Berhad (BIMB) had a virtual monopoly on Islamic banking activities for 10 years. The successful functioning of BIMB prepared a comfortable ground in which an ambitious experiment for a full-fledged Islamic financial system could be undertaken.

It may also be argued that in the nascent stage of development of Islamic banking, it was probably necessary to give some kind of monopoly advantage to BIMB. However, once the viability and feasibility of Islamic banking techniques are established, the monopoly position has to give way to competition. Now the banking institutions offering Islamic banking products have to compete not only among themselves but also against the conventional financial institutions; thus the reason why it is necessary that the number of financial institutions offering Islamic banking products must be expanded and these institutions must be linked together to form a money market as the traditional banking institutions do (Ahmed, 1997).

The long-term objective of the central bank has been to create an Islamic banking system to function on a parallel basis with the conventional system. A single Islamic bank does not constitute a system. A banking system, whether Islamic or conventional, would require the following three vital ingredients to qualify as a system (Bank Negara Malaysia, 1994):

1. A large number of Players: There must be an adequate number of different types of institutions participating in the system. This is required to provide depth to the system.

2. A Broad variety of Instruments: A large variety and range of different types of instruments must be available to meet the various needs of the financial institutions and the customers.

3. An Islamic Interbank Market: There must be an efficient and effective inter-bank money market to link the players (institutions) and the instruments.

In addition to the above requirements, which apply to all systems, an Islamic banking system must also reflect socio-economic values of Islam. In other words, it must be Islamic in substance and not merely in label (i.e., substance over form).

Recognising the above, the authorities adopted a step-by-step approach to achieve the objective of developing an Islamic banking system to complement conventional banking. It was decided that, for the first 10 years (1983-1992), there should be only one Islamic bank; namely, BIMB, and that during this period, a large number of Islamic financial instruments should be developed. With only one Islamic bank operating, it would be much easier to develop and test out new instruments on a careful and prudent basis. 


\section{A Large Number of Players}

Having achieved the objective of ensuring a large number and broad variety of Islamic financial instruments, it was time to move on to achieve the two other objectives; namely, a large number of institutions offering Islamic banking services and an Islamic money market to link the institutions with the instruments (Bank Negara Malaysia, 1994). The Central Bank considered three options with regard to increasing the number of institutions offering Islamic banking services:

1. The first option was to allow the setting-up of new Islamic banks.

2. The second option was to allow the existing financial institutions to set up subsidiaries to offer Islamic banking services.

3. The third option was to allow existing financial institutions to offer Islamic banking services using their existing infrastructure and branches.

After careful consideration of the various factors, the Central Bank chose the third option. It was felt that it provided the most effective and efficient method of increasing the number of institutions offering Islamic banking services at the lowest cost and within the shortest time frame. The first two options would have been costly, given that the cost of setting up a branch is about RM 500,000. Moreover, setting up new branches would take time and theirs is the related problem of recruiting new staff in an environment of labour shortage. The third option, on the other hand, allowed the existing infrastructure of the banking system, including the existing branches and staff, to be used in offering Islamic banking services.

\section{The Interest-Free Banking Scheme (SPTF)}

A scheme was therefore developed to allow the existing financial institutions to offer Islamic banking services and was launched on a pilot basis on March 4, 1993. The scheme was named Skim Perbankan Tanpa Feadah (SPTF) - (the English version is Interest-free Banking Scheme).

All commercial banks, merchant banks and finance companies are eligible to participate in SPTF and discount houses may be included later. A financial institution willing to participate in SPTF is required to set up an Interest-free Banking Unit (IBU) in the head office with the following functions:

- $\quad$ To attend to all aspects concerning the operations of the SPTF, including policy and procedural matters

- $\quad$ To liaise with other departments in the financial institution to ensure smooth operations of SPTF

- $\quad$ To ensure that all funds pooled into the Interest-free Banking Fund are channelled into financing and investment activities on the basis of Islamic principles

- To arrange for training of staff of Islamic banking so as to ensure the smooth and effective implementation of the SPTF

- $\quad$ To arrange for compilation and submission of such returns, as may be required to be submitted to Bank Negara from time to time

- $\quad$ To ensure that all directives and guidelines issued by Bank Negara pertaining to the SPTF are strictly complied with

- To undertake on-going research and development in Islamic banking for further enhancement of the Islamic financial system

The IBU has to be headed by a senior and experienced Muslim officer and manned by qualified staff. The financing institution joining SPTF is also required to maintain a working fund, named Interest-free Banking Fund (IBF) with a minimum amount to be determined by Bank Negara from time to time. The present minimum amount present is RM 1 million. The IBF has the following features:

- $\quad$ It is funded by way of an allocation by the head office of the bank.

- $\quad$ It is placed under the IBU to fund the operations of the SPTF.

- $\quad$ Profits and fees earned by the SPTF are to be credited into the IBF. 
The SPTF, which was launched on March 4, 1993, on a pilot basis involving the three largest domestic commercial banks - Malayan Banking Berhad, Bank Bumiputra Malaysia Berhad, and United Malayan Banking Corporation Berhad - and it ran smoothly during the pilot run period. The second phase of the SPTF was launched on August 21, 1993, whereby 10 additional financial institutions joined the scheme. At the end of December, 1993, a total of 21 financial institutions had obtained the Central Bank's approval to offer Islamic banking facilities.

\section{A Broad Variety of Instruments}

By the beginning of 1993, a total of 21 Islamic banking products were successfully developed by the Central Bank and, therefore, one of the three requirements for a full-fledged Islamic financial system was achieved (Bank Negara Malaysia, 1994). The list of products is shown in Table 1.

Table 1: The New Islamic Banking Products

\begin{tabular}{|c|c|c|}
\hline S. No. & Product & Islamic Concept \\
\hline (i) & Current account & Al-Wadiah Yad Dhamanah \\
\hline (ii) & Savings account & Al-Wadiah Yad Dhamanah \\
\hline (iii) & General investment account & Al-Mudarabah \\
\hline (iv) & Special investment account & Al-Mudarabah \\
\hline (v) & Investment in Government Investment Certificate & Al-Qard al-Hasan \\
\hline (vi) & Investment in shares/share financing & Al-Wakalah or Al-Mudarabah or Bay' Bithaman Ajil \\
\hline (vii) & House financing & Bay'Bithaman Ajil \\
\hline (viii) & Vehicle financing & Bay' Bithaman Ajil or Al-Ijarah Thumma Al-Bay' \\
\hline (ix) & Working capital financing & Al-Murabahah \\
\hline$(\mathrm{x})$ & Project financing & Al-Mudarabah or Al-Musharakah \\
\hline (xi) & Financing for the acquisition of assets & Bay'Bithaman Ajil \\
\hline (xii) & $\begin{array}{l}\text { Islamic Export Credit Refinancing } \\
\text { Pre-shipment } \\
\text { Post-shipment }\end{array}$ & Al-Murabahah/Bay'Al-Dayn bi Al-Dayn \\
\hline (xiii) & $\begin{array}{l}\text { Islamic Accepted Bills } \\
\text { Import/Purchases } \\
\text { Export/Sales }\end{array}$ & Al-Murabahah/Bay'Al-Dayn bi Al-Dayn \\
\hline (xiv) & Letters of credit facilities & Al-Wakalah or Al-Murabahah or Al-Musharakah \\
\hline (xv) & Shipping guarantee & Al-Kafalah \\
\hline (xvi) & Letter of guarantee & Al-Kafalah \\
\hline (xvii) & Overdraft facilities & Al-Qard al-Hasan \\
\hline (xviii) & Leasing & Al-Ijarah \\
\hline (xix) & Underwriting of Islamic bonds & Al-Ujr \\
\hline$(\mathrm{xx})$ & Bills operations & Al-Ujr/Al-Wakalah \\
\hline (xxi) & Welfare loans & Al-Qard al-Hasan \\
\hline
\end{tabular}

\section{An Islamic Interbank Market}

By the end of 1993, therefore, two out of the three requirements for a full-fledged Islamic banking system had been achieved; namely, a large number of institutions participating in the system and a large number and broad variety of instruments. The remaining objective that had to be met in bringing about a comprehensive Islamic banking system in Malaysia was the setting up of an Islamic money market to link the institutions and the instruments.

An Islamic money market was implemented in the Malaysian financial system in effect from January 3, 1994 (Bank Negara Malaysia, 1994). The Islamic inter-bank money market covers the following aspects:

- Inter-bank trading in Islamic financial instruments;

- Islamic inter-bank investments

- Islamic inter-bank cheque clearing system 
The Malaysian Islamic inter-bank money market that began on January 3, 1994 was the first Islamic money market in the world.

\section{TRADING IN ISLAMIC FINANCIAL INSTRUMENTS}

Bank Islam Malaysia and all SPTF financial institutions are allowed to trade in the Islamic financial instruments, such as Islamic bankers' acceptances, among themselves. More Islamic instruments will be introduced in due course for this purpose.

\section{Islamic Interbank Investment}

Islamic inter-bank investment refers to the system whereby a SPTF bank can invest its surplus in another SPTF bank which has a deficit on the basis of Al-Mudarabah (profit-sharing). The features of this mechanism are as follows:

- $\quad$ The period of investment is from overnight to 12 months.

- $\quad$ The minimum amount of investment is RM 50,000.

- The profit-sharing ratio is based on the period of investment as follows:

$\circ$ For periods of less than or equal to one month, the profit-sharing ratio is 70:30 (i.e., 70 percent for the provider of the funds).

- For periods exceeding one month and up to three months, the profit-sharing ratio is 80:20.

$\circ$ For periods exceeding three months, the profit-sharing ratio is 90:10.

\section{Islamic Interbank Cheque Clearing System}

A clearing system was introduced at Bank Negara for Bank Islam Malaysia and the SPTF units of the commercial banks. Cheques with respect to these institutions will be segregated from the conventional cheques for clearing purposes from January 3, 1994. The Islamic inter-bank cheque clearing system is also based on the principle of Al-Mudarabah. At 12:00 midnight, during the automatic cheque clearing at Bank Negara Malaysia, SPTF banks (including Bank Islam Malaysia) having a deficit will automatically be funded from the surplus funds of other SPTF banks on the basis of the concept of Al-Mudarabah. If there is still a deficit after such funding, it will be funded by Bank Negara on the same principle; i.e., Al-Mudarabah. The profit ratio for this mechanism is 70:30 (i.e., 70 for the investor). The repayment will be effected from the next morning.

\section{The National Syariah Advisory Council on Islamic Banking and Takaful (NSAC-IBAT)}

Since the Interest-Free Banking Scheme (IFBS) was launched on March 4, 1993, the number of financial institutions authorised to offer Islamic banking products increased sharply from three commercial banks in March 4, 1993 to 21 financial institutions at the end of December 31, 1993, and to 51 institutions by December 31, 1997.

We know that Bank Islam Malaysia Berhad has gotten a Shari'ah Supervisory Board from the very beginning. This is the standard practice in all Islamic banks around the world. The Shari'ah Board was adopted by all banks in order to ensure that the banking practice does not trespass the boundaries of Halal and enter into the realm of what has been prohibited (Haram). However, the available official documents like 'Money and Banking in Malaysia-1994' or the annual reports of Bank Negara do not show as to how the financial institutions under the SPTF will be supervised in Shari'ah-wise.

The establishment of the National Syariah Advisory Council on Islamic Banking and Takaful on 1 May, 1997 was a glad tiding for Islamic banking and finance in Malaysia. The Council consists of 10 members, including a foreign representative from Sudan, according to the Annual Report of Bank Negara of 1997. The Council acts as a Shari'ah Supervisory Board for all institutions under the SPTF scheme. As a result, the customers' confidence in the banking system increased. 
In this phase, we have seen the establishment of new financial instruments and markets along with the National Shari'ah Advisory Board. Here onwards, Malaysia started enjoying the fruits of dual banking system by encouraging all its citizens from different cultural and religious background to participate in the development process by their savings and capital accumulation within the formal financial system.

\section{CONCLUSION}

From a humble beginning in 1983, the Malaysian Islamic banking system (MIBS), according to the Financial Stability Report (Bank Negara Malaysia, 2011), reached an impressive average of just over 22 percent in the year ending 31 December, 2011 - well above the 20 percent set by the Financial Sector Master Plan of Malaysia for the Islamic banking sector in terms of market share of assets, deposits, and financing of the total banking sector. As shown in Table 2, by the end 2011, out of the total 58 licenced banking institutions in Malaysia, 21 of them were Islamic.

Table 2: Licensed Banking Institutions

\begin{tabular}{|c|l|c|}
\hline No. & \multicolumn{1}{|c|}{ Type } & Number \\
\hline 1 & Commercial Banks & 25 \\
\hline 2 & Islamic Banks & 16 \\
\hline 3 & International Islamic Banks & 5 \\
\hline 4 & Investment Banks & 15 \\
\hline 5 & Other Financial Institutions & 2 \\
\hline & Total & $\mathbf{5 8}$ \\
\hline
\end{tabular}

Source: Bank Negara Malaysia, 2011

Today when you walk into more than 50 banks and financial institutions with branches in Malaysia, you will find two separate alternatives for their customers. On one side, there is the conventional banking area and on the other side is a separate window for those who want to carry on their banking transactions according to the Islamic principles. The two systems co- exists in parallel. In such a multi-ethnic and multi-religious country, customers get the products and services they like which is a great achievement in serving and satisfying your customers' needs.

As we have seen, the development of Malaysia's Islamic banking and financial system is tied up with its social and economic policy. The Islamic banking and financial system is expected to improve the economic condition of Muslims in Malaysia and bring them up to par with their countrymen of Chinese origin. For this reason, establishment of Malaysia's Islamic banking and financial system was fully supported by the country's top leadership - Prime Minister, Finance Minister, the Central Bank, the Parliament, and the public in general.

Table 3: List of Licensed Islamic Banks

\begin{tabular}{|c|l|l|}
\hline No. & \multicolumn{1}{|c|}{ Ownership } \\
\hline 1 & Affin Islamic Bank Berhad & Local \\
\hline 2 & Al Rajhi Banking \& Investment Corporation (Malaysia) Berhad & Foreign \\
\hline 3 & Alliance Islamic Bank Berhad & Local \\
\hline 4 & AmIslamic Bank Berhad & Local \\
\hline 5 & Asian Finance Bank Berhad & Foreign \\
\hline 6 & Bank Islam Malaysia Berhad & Local \\
\hline 7 & Bank Muamalat Malaysia Berhad & Local \\
\hline 8 & CIMB Islamic Bank Berhad & Local \\
\hline 9 & Hong Leong Islamic Bank Berhad & Local \\
\hline 10 & HSBC Amanah Malaysia Berhad & Foreign \\
\hline 11 & Kuwait Finance House (Malaysia) Berhad & Foreign \\
\hline 12 & Maybank Islamic Berhad & Local \\
\hline 13 & OCBC Al-Amin Bank Berhad & Foreign \\
\hline 14 & Public Islamic Bank Berhad & Local \\
\hline 15 & RHB Islamic Bank Berhad & Local \\
\hline 16 & Standard Chartered Saadiq Berhad & Foreign \\
\hline
\end{tabular}

Source: Bank Negara Malaysia, 2011 
Among the countries with free market economic system, Malaysia has also emerged as the first country to have a dual banking and financial system with 16 full-fledged Islamic banks (see Table 3). The Malaysian model has been recognised by many Islamic countries as the model for the future. Moreover, they have also shown a keen interest in studying the Malaysian system in order to implement a similar system in their respective countries.

Finally, the Malaysian experience in Islamic banking and finance has confirmed the following facts which can be learned and adopted by other Muslim counties aspiring for better economic development and standard of living:

- No one can deny that Islamic banks have succeeded in attracting categories of investors who did not previously have dealings with conventional banks. The Islamic banks have thus contributed positively in raising the level of national savings and investment.

- $\quad$ A strong case can be made on religious ground for the argument that an Islamic banking system could attract resources from devout savers and can be used in financing development.

- If an Islamic banking and financial system is introduced as a complement to the conventional banking system, overall savings held within the financial system will increase because Islamic banks would not only offer the savers a variable pecuniary yield on investment deposits, but also a non-pecuniary return in the form of religious satisfaction.

- Only Islamic banks can motivate Muslims to increase savings and reduce hoarding. This kind of motivation will enhance their participation in the development process, contribute to the process of savings mobilisation and capital accumulation, provide employment opportunities, and improve the standard of living of the society.

- With the creation of Islamic banks, the menu of savings instruments expands and no existing savings outlet is left out.

- With vision, political will and proper planning, it is possible to gradually create an Islamic banking and financial system without disturbing the existing conventional banking and financial system of the concerned country; Malaysia did it successfully (see Table 4).

Table 4: Chronological Arrangement of the Steps Taken Toward Dual Banking System

\begin{tabular}{|l|l|}
\hline Year & \multicolumn{1}{|c|}{ Steps Achieved } \\
\hline 1963 & Pilgrims Saving Corporation \\
\hline 1969 & Tabung Haji (Pilgrims Management and Fund Board) \\
\hline 1981 & National Steering Committee on Islamic Banks \\
\hline 1983 & Bank Islam Malaysia Berhad \\
\hline 1983 & Syarikat Al-Ijarah Sdn. Bhd. \\
\hline 1983 & Government Investment Certificate (GIC) \\
\hline 1984 & Al-Wakalah Nominee Sdn. Bhd. \\
\hline 1984 & Malaysia Islamic Development Foundation \\
\hline 1985 & Syarikat Takaful Malaysia Sdn. Bhd. \\
\hline 1990 & Lubuan International Offshore Financial Centre \\
\hline 1993 & Interest-Free Banking Scheme (SPTF) \\
\hline 1993 & 21 Islamic Banking Products developed by BNM. \\
\hline 1994 & Islamic Inter-Bank Market \\
\hline 1994 & Islamic Inter-Bank Cheque Clearing System \\
\hline 1997 & National Syariah Advisory Council for Islamic Banking and Takaful \\
\hline 2001 & Malaysian Financial Sector Master Plan \\
\hline 2003 & Syariah Advisory Council accorded as the sole authoritative body on Syariah matters \\
\hline 2006 & Liberalization of the financial system to allow foreign players to participate \\
\hline 2007 & Capital Markets and Services Act 2007 \\
\hline 2009 & Recognizing the duality of the banking system by law: Act 701 - Central Bank of Malaysia Act 2009 \\
\hline
\end{tabular}

Source: Bank Negara Malaysia 


\section{AUTHOR INFORMATION}

Khiyar Abdalla Khiyar is an assistant professor at the Department of Economics and Finance, Gulf University for Science and Technology, Kuwait. Since 2005 he has been teaching Islamic finance and principle of economics within the department. He also taught at the Department of Management \& Marketing some management courses. $\mathrm{He}$ did his undergraduate degree in engineering and his master degree in MBA (Finance) from the Faculty of Management Science, University of Pune, India. In 2001 he completed his Ph.D. from the Faculty of Management Science, Dr. B.A. Marthwada University, Aurangabad, India. E-mail: AbdallaK@ gust.edu.kw

\section{REFERENCES}

1. Ahmed, Ausaf, (1997), "Towards an Islamic Financial Market”, IDB-IRTI-Research Paper No. 45, Jeddah, Saudi Arabia.

2. Ahmed, Mahmood, (1988), "The Success of Islamic Banks”, Bank Prikrama, Vol. XIII, No. 314, Sept. \& Dec., 1988.

3. Bank Negara Malaysia, (1983 to 2011), “Annual Reports, all issues 1983 - 2011”.

4. $\quad$ Bank Negara Malaysia, (1994), "Money and Banking in Malaysia", 1994, p. 327.1997, p. 35.

5. Bank Negara Malaysia, (2011), "Financial Stability and Payment Systems Report 2011".

6. Institute of Bankers Malaysia, (1989), "Islamic Banking in Malaysia", Bankers' Journal of Malaysia, April, 1989, p. 63.

7. Cooke, Kieran, (1995), "Two systems exist side by side”, in Financial Times, November 20, 1995.

8. Hussain, Awang Adek, (1998), "Islamic Financing Opportunities in Labuan IOFC", New Horizon, February, 1998, pp. 6-11.

9. Zakaria, Man (1988), "Islamic Banking: the Malaysian Experience", Arif, Mohammed, "Islamic Banking in South East Asia"1988, pp. 67-102.

\section{INFORMATIVE WEBSITES}

www.bnm.gov.my: Bank Negara Malaysia (Central Bank of Malaysia) www.mifc.com: Malaysian International Islamic Financial Centre (MIFC) www.iimm.bnm.gov.my: Islamic Interbank Money Market www.bondinfo.bnm.gov.my: Malaysian Bonds Market Information www.sc.com.my: Securities Commission Malaysia www.pidm.gov.my: Malaysian Deposit Insurance Corporation 


\section{NOTES}

